\title{
Meet the 2021 Lee Ann Fujii Diversity Fellowship Program Travel Grant Recipients
}

\author{
JASMINE SCOTT | PROGRAM MANAGER, DIVERSITY AND INCLUSION PROGRAMS
}

T

he APSA Lee Ann Fujii Diversity Fellowship Program (DFP) travel grant provides support for the professional development of APSA Diversity Fellows and alumni at the APSA Annual Meeting. The grant is named in honor of Dr. Lee Ann Fujii.

Dr. Fujii was a professor at the University of Toronto who researched and published in the area of political violence, ethnicity and race, African politics (especially Rwanda and the Great Lakes), field methods, and research ethics. Support for this grant, which is in its second year, has been generously provided by the Fujii family and Dr. Fujii's friends and colleagues. To learn more about Dr. Fujii, please visit "Remembering Lee Ann Fujii" at https://politics.utoronto.ca/2018/03/remembering-lee-ann-fuiii/.

Priority is given to fellows and alumni whose research, teaching, or mentoring focuses in one or more of the areas of political violence, ethnicity and race, African politics, racial violence in the US South, comparative politics, international relations, conflict processes, research ethics, or qualitative and interpretative methods. Learn more about the Lee Ann Fujii Travel Grant at https://apsanet. org/dfp/travelgrant.

\section{MAYA CAMARGO-VEMURI}

Maya Camargo-Vemuri is a PhD student at the Johns Hopkins University School of Advanced International Studies. Her dissertation examines violence in genocide, attempting to establish patterns within and across contemporary cases. More broadly, Camargo-Vemuri looks at political violence, repression, and marginalization, usually within authoritarian regimes or identity-based conflicts. As such, her research usually looks at cases of genocide, ethnic cleansing, mass atrocity, or human rights violations, and the role nationalism and propaganda have in perpetuating, supporting, and furthering certain norms and behaviors in cases of violence and repression.

The Lee Ann Fujii Travel Grant was used to support Camargo-Vemuri's engagement with other scholars of violence and conflict at APSA 2021, including her role in hosting this year's Women in Conflict Studies (WICS) networking event.

\section{OLIVIA COOK}

Olivia J. Cook is a multi-passionate, innovative leader who thrives on helping institutions and organizations develop their human capital to gain greater efficiencies and productivity. As a higher educational professional and lifelong scholar, her work focuses on the authentic leadership style development process of African American women senior leaders, which has amassed over 3.5 million impressions. As a result, she has consulted for state agencies and academic departments on topics related to leadership, entrepreneurship, and diversity and inclusion. Cook, a 2017-2018 MFP recipient, utilized the Lee Ann Fujii Travel Grant to support efforts as she prepared to share her research at the 2021 APSA Annual Meeting. She presented her paper entitled "Beyond the Skin: Authentic Leadership and African American Women Senior Leaders."

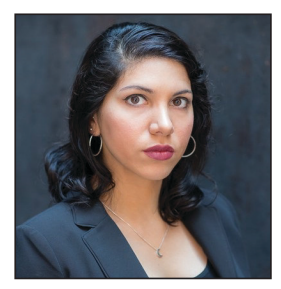

A native of Auburn, AL and a tri-alumna of Auburn University, Cook holds a Bachelor's Degree in Polymer and Fiber Engineering, and a minor in Spanish as well as a Masters and PhD in Public Administration and Public Policy.

\section{GREGORY LESLIE}

Gregory John Leslie, Jr., is a PhD candidate in the political science department at the University of California, Los Angeles where he also expects to earn a master's degree in statistics. He graduated from the honors program at New York University with a BA in international relations. At NYU, he worked with human rights organizations such as Amnesty International, Asia Initiatives, and the World Economic Forum.

Prior to graduate school, he worked as an organizer, campaign manager, and political consultant for candidates such as Barack Obama and Eric Garcetti. Currently, he is a Co-Principal at Blue Wave Strategies which provides data-analytic services to progressive campaigns. His published research examines race and politics broadly and his dissertation project examines the political psychology of mixed-race individuals, both in the United States and abroad.

\section{AUSTIN NELSON}

Austin Nelson is a PhD student in the department of government and a JD student in the school of law at the University of Texas at Austin. He holds an MPPA from Baylor University and a BA summa cum laude from Hendrix College. His primary field of research is public law. Nelson is a 2020-2021 Dan Searle Fellow of the Institute for Humane Studies and a 2018-2019 APSA Minority Fellow.
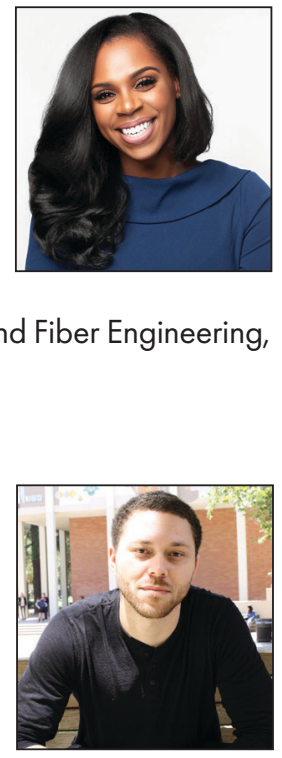
He previously served as co-chair of APSA's Committee on the Status of Graduate Students in the Profession. Nelson's work has appeared in the Texas Law Review and the Texas Review of Law \& Politics. In 2023-2024, he will be a judicial law clerk for Chief Judge Lavenski Smith of the US Court of Appeals for the Eighth Circuit. Nelson utilized the Lee Ann Fujii Travel Grant to attend the 2021 APSA Annual Meeting. He presented his paper comparing different approaches to militant democracy (or defensive democracy) in the constitutions of developing countries.

\title{
TYE RUSH
}

Tye Rush is a doctoral candidate in the department of political science at the University of California, Los Angeles. Broadly, Tye specializes in issues of race, ethnicity, and politics but his research examines the Voting Rights Act, voting rights, and election administration. His dissertation takes a holistic approach, examining legislator intent behind voter ID laws, by using historical context around restrictive voting laws to establish the link between the restrictive voting laws of the past and those of today in the literature.

Born and raised in San Bernardino, CA, Tye holds a bachelor's degree in political science and public service from the University of California, Riverside. Currently, Tye is a senior policy fellow at the UCLA Voting Rights Project, a Ford Foundation Dissertation Fellow, and a University of California President's Pre-Professo-

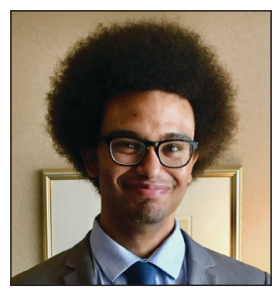
riate fellow. Previously, Tye served as a research fellow at the UCLA Institute for Inequality and Democracy at Luskin and as the Voting and Redistricting Fellow at Common Cause. Tye utilized the Lee Ann Fujii Travel Grant to present his paper, "Are Voter Identification Laws an Electoral Strategy?" at the 2021 APSA Annual Meeting.

\section{0-2021 Editors' Report for PS: Political Science \& Politics}

\author{
PHILLIP ARDOIN | COEDITOR
}

PAUL GRONKE | COEDITOR

MARAH SCHLINGENSIEPEN | INTERIM MANAGING EDITOR

PS: Political Science \& Politics is in its 54th year of publication. PS occupies a unique niche among the APSA porffolio of publications as an outlet for brief and non-technical articles featuring new research, political science commentary and research on timely political and social events, research into and discussion of the political science discipline, and scholarship on teaching and pedagogy.

This is our final year as editors. Over our eight-year tenure, we hope that we have successfully stewarded the journal during a period of rapid change in the profession and in the academy. We were the first faculty editorial team at PS, and we could not have been successful without the support of Barbara Walthall, who helped manage the transition and mentored our current managing editor, Celina Szymanski. Jon Gurstelle, Steve Smith, our partners at Cambridge University Press, and the Publication Committee of the APSA Council, and our Editorial Board, were also instrumental in helping us move the journal from an in-house publication to a fully peer-reviewed publication.

During the last two years, we have focused on systematizing and documenting our editorial policies and procedures, expanding our social media profile, and working with the APSA Council and staff to ensure a smooth transition to the next editorial team. We continue to advocate for regular communications between the editorial managers for all the APSA journals, standardized reporting on the demographics of authors and peer reviewers, and substantially similar policies across the journals on issues such as data deposit and transparency. Some standardization makes things easier for authors and reviewers, improves the ability of the Council and members of the profession to review and compare editorial performance and evaluation, and reduces the load for editorial teams.
Among the other things we have done this year to start to prepare for the editorial transition:

- Completed a data deposit policy to improve replicability and transparency;

- Continued to systematize submission and peer review policies for symposia and spotlights;

- Continued to reach out to underrepresented scholars, scholars outside the United States, and scholars from institutions with more teaching and service orientations.

- Requested several Board members to extend their term to maintain continuity;

- Recruited a small number of new Board members in order to have some institutional memory for the new team.

We will, of course, be available as a resource for the new team when they take over the journal in September 2022.

$P S$ is one of the primary outlets for research on the profession, and we've been proud to publish important articles and symposia that highlight the challenges of broadening and diversifying our profession (and academia) and combating conscious and unconscious biases in hiring, promotion, and peer review. We feel an important sense of responsibility to provide an outlet for disciplinary debates, but this has also opened up PS to some controversy as debates that first appear in our pages spill out into social media. We thank our Board, the Publications Policy Committee, and the APSA leadership for helping us navigate these discussions.

As examples, we have recently published and have upcoming symposia and spotlights on: 